
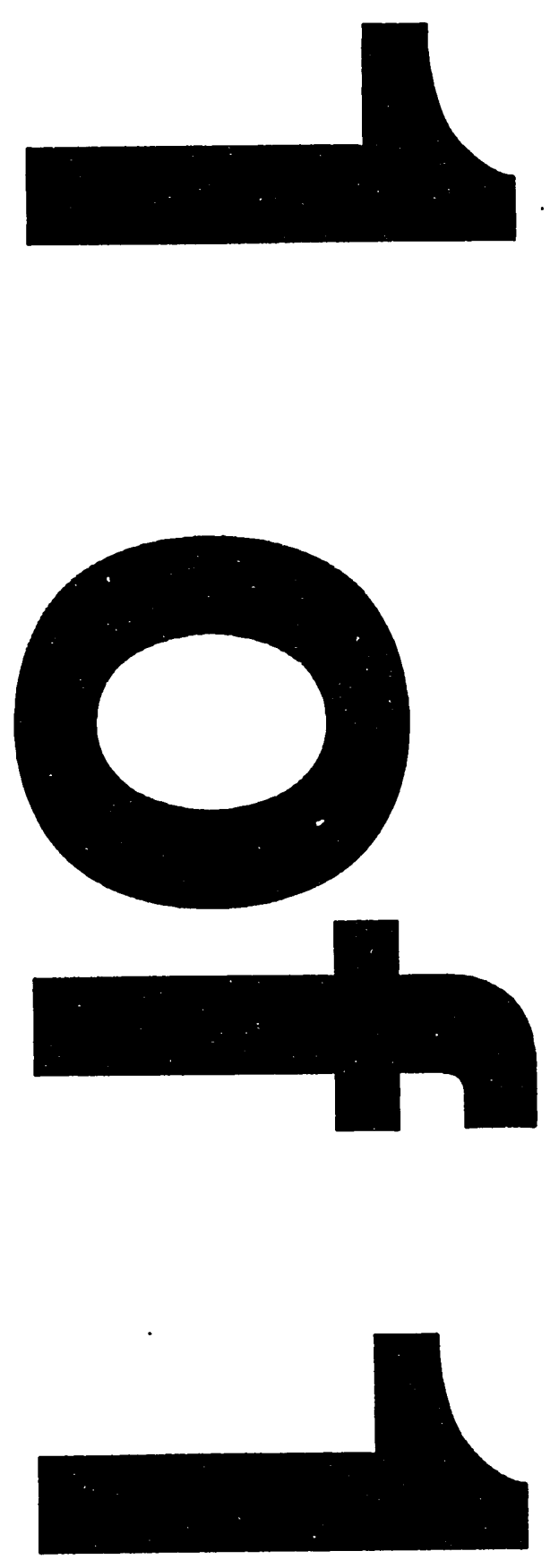


\section{F/H SEEPAGE BASIN GROUNDWATER PROCESS TANK SETTLING CHARACTERIZATION TASK TECHNICAL PLAN}

by

J. L. Siler

Savannah River Site

Aiken, South Carolina 29808

This paper was prepared in connection with work done under the above contract number with the U. S.

Department of Energy. By acceptance of this paper, the publisher and/or recipient acknowledges the U. S. Government's right to retain a nonexclusive, royalty-free license in and to any copyright covering this paper, along with the right to reproduce and to authorize others to reproduce all or part of the copyrighted paper. 


\section{DISCLAIMER}

This repon was prepared as an account of work sponsored by an agency of the United States Government. Neither the United States Government nor any agency thereof, nor any of their employees, makes any warranty, express or implied, or assumes any legal liability or responsibility for the accuracy, completeness, or usefulness of any information, apparatus, product, or process disclosed, or represents that its use would not infringe privately owned rights. Reference herein to any specific commercial product, process, or service by trade name, trademark, manufacturer, or otherwise does not necessarily constitute or imply its endorsement, recommendation, or favoring by the United States Government or any agency thereof. The views and opinions of authors expressed herein do not necessarily state or reflect those of the United States Government or any agency thereof.

This report has been reproduced directly from the best available copy.

Available to DOE and DOE contractors from the Office of Scientific and Technical Information, P. O. Box 62, Oak Ridge, TN 37831; prices available from (615) $576-8401$.

Available to the public from the National Technical Information Service, U. S. Department of Commerce, 5285 Port Royal Rd., Springfield, VA 22161 
WESTINGHOUSE SAVANNAH RIVER COMPANY

SAVANNAH RIVER TECHNOLOGY CENTER

WSRC-RP-93-1217

Keywords: F/H Seepage Basin

Facility, Particulate Settling,

Groundwater Remediation

August 31, 1993

CC: W. L. Tamosaitis, 773A

J. P. Bibler, 773A

P. E. Lowe, 773-42A

L. M. Nelson, 773-43A

R. N. Strom, 773-42A

J. A. Adams, CCC4

B. T. Butcher, CCC4

M. E. Gorden, CCC4

C. M. Lewis, CCC4

B. A. Hamm, CCC4

B. G. Schappell, CCC4

S. M. Serkiz, CCC4

M. R. Welty, CCC4

TIM, 703-43A, Rm.26 (4)

To: R. H. Hsu, 773-43A

From: J. L. Siler, 773-43A

\section{F/H SEEPAGE BASIN GROUNDWATER PROCESS TANK SETTLING CHARACTERIZATION TASK TECHNICAL PLAN(U)}

\subsection{INTRODUCTION}

The Environmental Restoration (ER) Department is responsible for environmental remediation projects on Site. ER requested Interim Waste Technology Section (IWTS) to conduct a treatability study to develop a system which would reduce the groundwater contaminant levels in the aquifers at the $\mathrm{F} / \mathrm{H}$ seepage basins.

A task technical plan [Siler(1993)] has been initiated to support the remediation system development. The work described in the referenced plan is directed towards the characterization of the influent, effluent and precipitated sludge that will be generated during treatment. This task plan provides the methodology for conducting further investigations into the behavior of groundwater in the tanks. This task plan is not designed to answer any design questions but is directed towards providing operating data for the treatment units. 
R. H. Hsu

WSRC-RP-93-1217

Page 2

August 31, 1993

Potential concerns exist that are related to the settling characteristics of particulate matter in the groundwater. During periods of operation, the injection system water tank and extraction system water tank will probably maintain some minimum water level. During periods of extended treatment system downtime, groundwater may remain within the injection system water tank and extraction system water tank. The settling of particulate matter is of potential concern due to the following:

- Radioactivity-related safety issues may need to be investigated and documented.

- Accumulation of particulate matter will reduce the tanks' operating volumes.

- The characteristics of the settled particulate matter need to be determined and appropriate cleaning and/or decommision procedures developed for the tanks.

\subsection{TASK DELIVERABLES}

\section{Reports}

Reports documenting the results of this research project will be compiled as internal WSRC reports. These reports will be reviewed and received by ER and other appropriate organizations. The reports will be issued a WSRC-RP-93-\#\# number.

\subsection{TASK REOUIREMENTS}

The requirements of this task are to:

- Divide each composite sample into two portions, one portion will be archived for potential future uses.

- Determine if $\mathrm{pH}$ change in the composite sample occurs due to exposure to ambient air.

- Obtain qualitative characteristics of the settling process by visual inspection.

- Obtain radionuclide and chemical characteristics of the settled particulate through laboratory analysis for safety documentation.

\subsection{TASK PREREQUISITES}

\section{Task Technical Plan}

This task F. sul will be reviewed by ER. IWTS and ER will approve this Task Technical Plan.

\section{Task QA Plan}

The Task QA Plan developed for the task technical plan WSRC-RP-93-0941 will support this Task Technical Plan. IWTS and SRTC-QS will approve the Task QA Plan. No special training is necessary. Chain of custody will be addressed in the Task QA Plan. 
R. H. Hsu

WSRC-RP-93-1217

Page 3

August 31, 1993

\section{Procedure(s)}

IWTS will generate the required procedure(s) for operation of the test equipment. IWTS will approve the procedure(s).

\subsection{TASK ACTIVITIES AND DESCRIPTION}

\section{Experimental Procedure Outline}

The experimental studies to be conducted will be performed in laboratory B-122 (building 773-A) for the actual groundwater. The test solution will be actual well water from the F/H Area wells. All samples will be submitted for analysis in duplicate to SRTC and offsite laboratories. The offsite laboratories function will be governed according to QA level 1 requirements. Listed below is the experimental procedure.

Step 1. WELL WATER PROCUREMENT- Well water for this technical task plan is obtained through technical task plan WSRC-RP-93-0941. Four gallons from each of the two composite samples (one from F Area and one from H Area) are reserved for this technical task plan.

Step 2. WELL WATER SAMPLES PREPARATION - Each four gallon composite sample will be divided into one gallon and three gallon portions. The one gallon portion will be placed into an appropriate, clear, open container. The three gallon portion will be placed into an appropriate storage container for future use. The one gallon sample will be placed in an appropriate location where the sample will be undisturbed by other lab work and yet remain exposed to normal air flow.

Step 3. EXPERIMENTAL WORK - The one gallon container will be inspected twice per week for a three month period. The inspection shall include a visual inspection of water clarity and particulate accumulation, and a measurement of the $\mathrm{pH}$. A log book will be kept of all observations, both qualitative and quantitative.

Step 4. ANALYTICAL WORK - At the end of the three month period, the one gallon sample will be analyzed for Total Suspended Solids, heavy metals and isotopic content providing enough solids have settled to allow for a sufficient sample size. See Table 1 for a listing of constituents for which to analyze.

Step 5. THEORECTICAL WORK - Calculations will be made to estimate the amount of precipitation that will occur. A theoretical model such as the ESP program (developed by E. Orebaugh) may be used for this task.

Table 1. Constituents to be Analyzed

\begin{tabular}{|l|l|l|}
\hline Constituent & Analysis & SRTC/Offsite \\
\hline Organics & & \\
\hline Benzene & GC/MS & both \\
\hline Chloroethylene & GC/MS & both \\
\hline
\end{tabular}


R. H. Hsu

WSRC-RP-93-1217

Page 4

August 31, 1993

\begin{tabular}{|l|l|l|}
\hline Dichloroethylene & GC/MS & both \\
\hline Dissolved organic carbon & Filter then TC & both \\
\hline Methylene chloride & GC/MS & both \\
\hline Phenols & GC/MS & both \\
\hline Tetrachloroethylene & GC/MS & both \\
\hline Total Organic Carbon & TIC/TOC & both \\
\hline Trichloroethylene & GC/MS & both \\
\hline Trichlorflouromethane & GC/MS & both \\
\hline Bis(2-ethyl(hexyl))Phlalate & GC/MS & both \\
\hline 1,1 Dichloroethane & GC/MS & both \\
\hline Chloroform & GC/MS & both \\
\hline & & \\
\hline Metals & & \\
\hline Aluminum & ICP/MS \& AppIX & both \\
\hline Antimony & ICP/MS \& AppIX & both \\
\hline Arsenic & ICP/MS \& AppIX & both \\
\hline Barium & ICP/MS \& AppIX & both \\
\hline Cadmium & ICP/MS \& AppIX & both \\
\hline Calcium & ICP/MS \& AppIX & both \\
\hline Chromium & ICP/MS \& AppIX & both \\
\hline Cobalt & ICP/MS \& AppIX & both \\
\hline Copper & ICP/MS \& AppIX & both \\
\hline Cyanide & AppIX & both \\
\hline Dissolved inorganic carbon & Filter thenTIC & both \\
\hline Mercury & AA \& AppIX & both \\
\hline Lead & ICP/MS \& AppIX & both \\
\hline Manganese & ICP/MS \& AppIX & both \\
\hline Magnesium & ICP/MS \& AppIX & both \\
\hline Nickel & ICP/MS \& AppIX & both \\
\hline Chloride & IC \& AppIX & both \\
\hline Fluoride & IC \& AppIX & both \\
\hline Iron & ICP/MS \& AppIX & both \\
\hline Nitrate & IC \& AppIX & both \\
\hline Potassium & AA \& AppIX & both \\
\hline Selenium & ICP/MS \& AppIX & both \\
\hline Silver & ICP/MS \& AppIX & both \\
\hline Silicon & ICP/MS \& AppIX & both \\
\hline Sodium & ICP/MS \& AppIX & both \\
\hline Sulfate & IC \& AppIX & both \\
\hline pH & pH meter & both \\
\hline Thallium & AppIX & both \\
\hline Total Phosphates & EPA method & both \\
\hline Tributyl phosphate & GC & SRTC \\
\hline Vanadium & ICP/MS \& AppIX & both \\
\hline Zinc & ICP/MS \& AppIX & both \\
\hline Tin & ICP/MS * AppIX & both \\
\hline & & \\
\hline
\end{tabular}


R. H . Hsu

WSRC-RP-93-1217

Page 5

August 31, 1993

\begin{tabular}{|l|l|l|}
\hline Radionuclides & & \\
\hline Total Uranium & EPA method & Off \\
\hline U-233 & EPA method & Off \\
\hline U-234 & EPA method & Off \\
\hline U-235 & EPA method & Off \\
\hline U-236 & EPA method & Off \\
\hline U-238 & EPA nethod & Off \\
\hline Pu-238 & EPA inethcd & Off \\
\hline Pu-239 & EPA method & Off \\
\hline Pu-240 & EPA method & Off \\
\hline Pu-241 & Calculations & SRTC \\
\hline Pu-242 & Calculations & SRTC \\
\hline Tritium (H-3) & EPA method & Off \\
\hline Ra-226 & EPA method & Off \\
\hline Ra-228 & EPA method & Off \\
\hline Total Ra & EPA method & Off \\
\hline Sr-90 & EPA method & Off \\
\hline I-129 & EPA method & Off \\
\hline Cs-137 & EPA nethod & Off \\
\hline Co-60 & EPA method & Off \\
\hline Cu-244 & EPA method & Off \\
\hline Tc-99 & EPA method & Off \\
\hline Th-228 & EPA method & Off \\
\hline Th-232 & EPA method & Off \\
\hline Th-234 & EPA method & Off \\
\hline Am-241 & EPA method & Off \\
\hline Am-243 & Calculations & SRTC \\
\hline $\mathrm{C}-14$ & EPA method & Off \\
\hline Nb-94 & EPA method & Off \\
\hline Ni-59 & EPA method & Off \\
\hline Np-237 & EPA method & Off \\
\hline Se-79 & EPA method & Off \\
\hline Rb-87 & EPA method & Off \\
\hline Gross alpha & EPA method & Off \\
\hline Gross nonvolatile beta & EPA method & Off \\
\hline Cm-243 & EPA method & Off \\
\hline U-233 & EPA method & Off \\
\hline Ac-228 & EPA method & Off \\
\hline Sr-89 & Calculations & SRTC \\
\hline Th-230 & EPA method & Off \\
\hline Cm-242 & EPA method & Off \\
\hline Cm-243/244 & EPA method & Off \\
\hline Cm-246 & EPA method & Off \\
\hline Count pre-digested solids & EPA method & SRTC \\
\hline Other & & \\
\hline Solids content & TS, TDS, TSS & SRTC \\
\hline & & \\
\hline
\end{tabular}


R. B. Hsu

WSRC-RP-93-1217

Page 6

August 31, 1993

\begin{tabular}{|l|l|l|}
\hline Particle size distr. & Size Analyzer & SRTC \\
\hline BOD & EPA method & Off \\
\hline COD & EPA method & Off \\
\hline Determine oxygen state of chromium & ErA method & Off \\
\hline Modified TCLP & Acetic Acid Ext. & SRTC/Off \\
\hline
\end{tabular}

\section{Experimental Logistics}

These experiments will be conducted by J. L. Siler and IWT technicians using procedures/instructions. Data collected will be entered on data sheets by the technicians and also in a laboratory notebook by J. L. Siler.

The work with actual groundwater will be performed in the 773-A, B-122 laboratory. Ali onsite samples will be analyzed by ADS using cutomer-assisted QA level. The ICP/MS work will be exploratory in nature. Off-Site analyses will be handled by ADS.

\subsection{EXPERIMENTAL ACTIVITIES}

The following preliminary schedule outlines the experimental plan to be conducted:

1. Obtain samples from selected wells (August).

2. Perform experimental work (August 1993 through November 1993).

3. Conduct analyses (December 1993 through March 1994).

4. Issue final report (June 1994).

\section{CHANGES TO THE TASK TECHNICAL PLAN}

Minor changes to this task technical plan will be noted in laboratory notebook \#WSRCNB-90-256. Major revisions will result in a revised task technical plan. 


\section{R. H. Hsu}

WSRC-RP-93-1217

Page 8

August 31, 1993

\subsection{REFERENCES}

Siler, J. L., "F/H Seepage Basin Groundwater Influent, Effluent, and Precipitated Sludge Characterization Task Technical Plan (U)", WSRC-RP-93-0941, July 7, 1993.

\section{REVIEW AND APPROVALS}

Reviewed by:

M.R.Welty 9-13-93

M. R. Welty, R4bject Engineer, ER Date

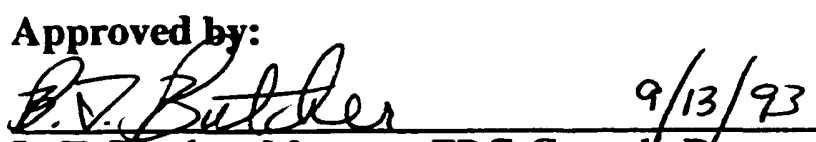

B. T. Butcher, Manager, ERG-Central Date

R-14.tatan 10/18/93

R. H. Hsu, Manager, IWTS Date

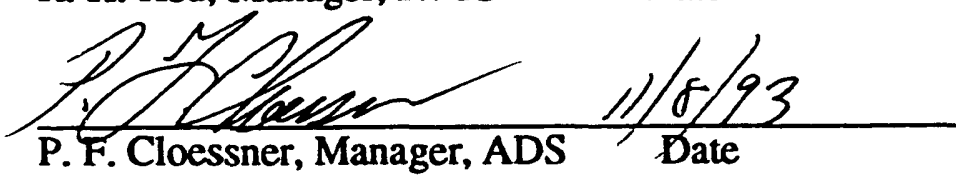

$\frac{\text { C.C.Mffar. }}{\text { J/C. Griffin, Manager, ADS }}$ 

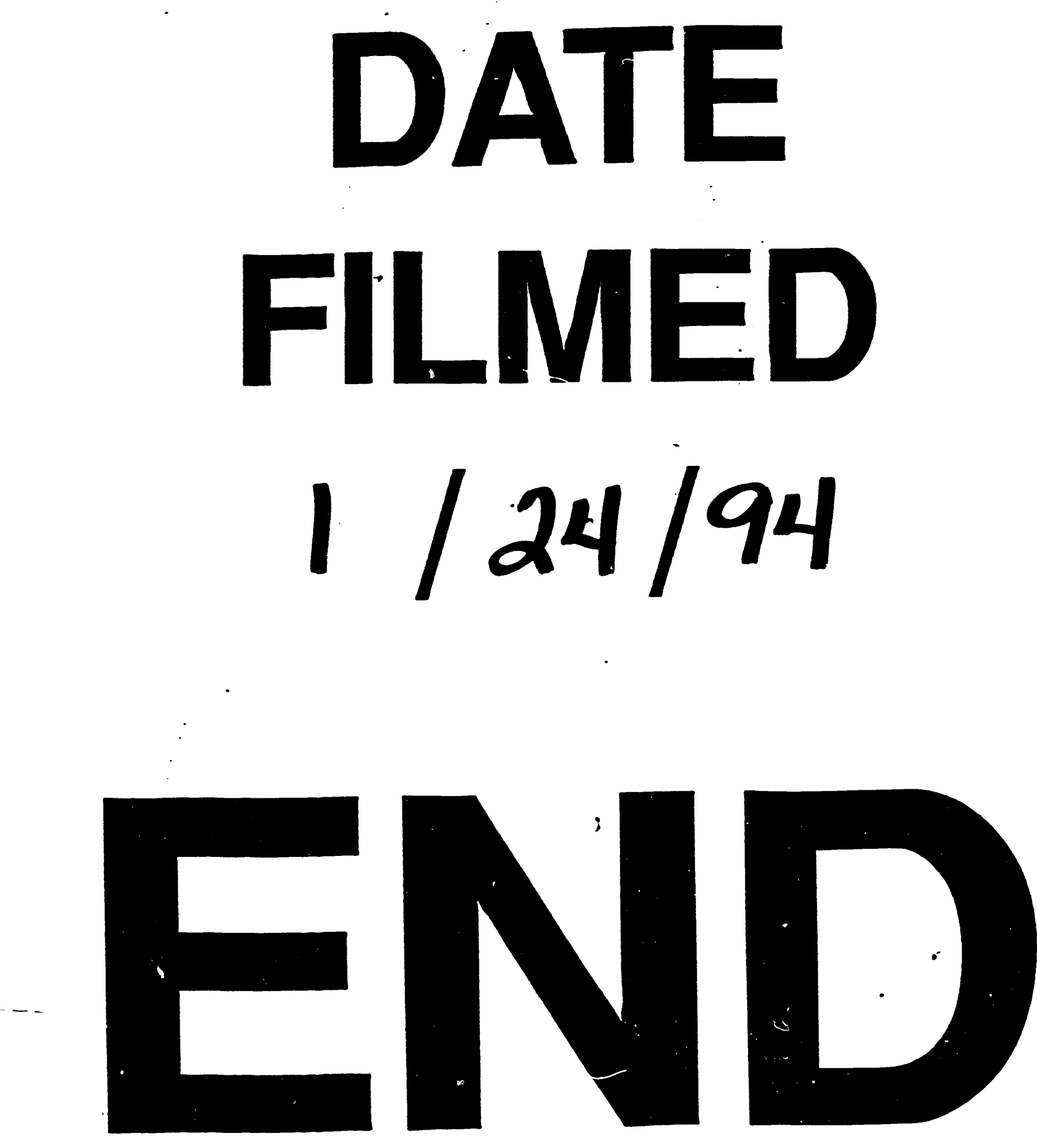